Article

\title{
Exploring the Effects of "Smart City" in the Inner-City Fabric of the Mediterranean Metropolis: Towards a Bio-Cultural Sonic Diversity?
}

\author{
Stella Sofia Kyvelou 1,*(D), Nicos Bobolos ${ }^{2}$ and Aggelos Tsaligopoulos ${ }^{3} \mathbb{D}$ \\ 1 Department of Economic and Regional Development, School of Science of Economics and Public Administration, \\ Panteion University of Social and Political Sciences, 17671 Athens, Greece \\ 2 Department of Interior Architecture, University of West Attica, 12243 Aegaleo, Greece; nbobolos@uniwa.gr \\ 3 Acoustic Ecology Laboratory, Department of the Environment, University of the Aegean, \\ 81100 Mytilene, Greece; tsaligopoulos@env.aegean.gr \\ * Correspondence: kyvelou@panteion.gr; Tel.: +30-210-9215981
}

Citation: Kyvelou, S.S.; Bobolos, N.; Tsaligopoulos, A. Exploring the Effects of "Smart City" in the Inner-City Fabric of the Mediterranean Metropolis: Towards a Bio-Cultural Sonic Diversity? Heritage 2021, 4 , 690-709. https://doi.org/10.3390/ heritage 4020039

Academic Editor: Nicola Masini

Received: 12 April 2021

Accepted: 21 April 2021

Published: 24 April 2021

Publisher's Note: MDPI stays neutral with regard to jurisdictional claims in published maps and institutional affiliations.

Copyright: (c) 2021 by the authors. Licensee MDPI, Basel, Switzerland. This article is an open access article distributed under the terms and conditions of the Creative Commons Attribution (CC BY) license (https:/ / creativecommons.org/licenses/by/ $4.0 /)$.

\begin{abstract}
Smart city", driven by digital technology is not only a technological but also a social, cultural and political project. A socially and culturally significant new urban ideal is born. This research paper is based on the narrative that the city appears as a palimpsest of interventions of all natures. History and shared memory, composition and superimposition, coherence and divergence are fundamental for its evolution. It is thus evident that "Smart city" as a rather new urban ideal, but also as a disruptive innovation process, cannot be conceived nor implemented all at once; it must follow analogous processes of buildup and stratification. On the other hand, sounds are part of cities, of their sensory landscape, of their identity. They are one of the urban markers, along with the visual landscape. In this context, the paper focuses on the sound identity of the inner-city areas of the Mediterranean metropolis, posing the following research question: What are the transformations that "Smart city" can cause to the sound identity of a city? In dense urban fabric with high-rise buildings, high rates of exploitation, frequent transgressions of the legal construction and least free space in private plots, what can be the prospects of using "smart transport", for enriching the city with positive soundscapes, thus improving its environmental quality? Following the metaphor of urban and acoustic palimpsest, we examine narratives of replacement of conventional cars with autonomous vehicles (AVs) and of private cars with car-pooling systems. The article concludes that spatialized intelligence can substantially and positively transform the sound identity of the Mediterranean metropolis and be the spearhead for an increase in bio-cultural sonic diversity. At least during the era when the city still appears as a palimpsest of interpositions, evoking the historic time.
\end{abstract}

Keywords: Mediterranean city; urban palimpsest; spatialized intelligence; autonomous vehicles (AVs); environmental noise; acoustic palimpsest; sound diversity

\section{Introduction}

The growth of the "Smart city" represents a real social and cultural transformation, analogous in importance to the birth of the industrial agglomerations of the 19th century and the development of the "networked city" as both an urban archetype and a material process of city conversion [1]. While the impact of this process on urban form is still uncertain, its effect on the historical dimension of inner-city structure can currently be detected. "Smart city" means living in cities that are changing in the rhythm of a series of abundant events, which can be monitored and experienced in real time [1]. However, this explosion of real-time events happens in tandem with a manifest privation of historical perspective, as if history was forever excluded in favor of an everlasting present [1,2] or a very near future that seems to be a simple augmentation of present conditions. The physical city/territory refers to inertia, to the long term, in other words a city/territory 
that develops through historic incidents, crises, and other social transformations. On the contrary, smart real-time city/territory is a world of instability, uncertainty and nearly zero inertia [2].

This research paper is based on the fact that the city appears as a palimpsest of interpositions of all natures. History and shared memory, composition and superimposition, coherence and divergence are fundamental for its evolution [3]. It is thus evident that "Smart city" as a rather new urban ideal [1], but also as a disruptive innovation process, cannot be conceived nor implemented all at once; it must follow analogous processes of buildup and stratification. In this context, the paper focuses on the sound identity of the inner-city areas of the Mediterranean metropolis, attempting to respond to the following research question: What are the gradual transformations that "Smart city" can cause to the sound identity of a city? Especially in dense urban fabric with high-rise buildings, high rates of exploitation, frequent transgressions of the legal construction and least free space in private plots, what can be the prospects of using "smart transport", for enriching the city with positive soundscapes, thus improving its environmental quality?

The tradition of outdoor activities in the Euro-Mediterranean cities is mainly due to their mild climate and the increased social interaction that Mediterranean people historically developed. Especially in the Ancient Greek, which is one of the richest languages globally, there is no word for "privacy", since privacy was not a common practice. As Pericles Giannopoulos stated in 1903 [4] "life in Greece is outdoor", which certainly means that no quietness is prevailing or pursued, in the Greeks' everyday life.

However, modern Euro-Mediterranean metropolises with their dense urban fabric, and several other medium-sized cities following their model of urban development, failed to offer appropriate open spaces, especially streets with decent sidewalks, squares and green spaces. Area, quality, condition and maintenance, accessibility, etc. of public and green spaces, are considered as important determinants of the quality of urban life (QOUL) in Europe [5]. Instead, there is an abundance of streets and only some rare squares, empty plots, yards, verandas and balconies used to be the public, quasi-public and semi-public spaces for socialization, children's games and so on. The mild sound environments that were formatted by this urban/social condition did not describe solely the urban place, but also the urban time (morning, noon, afternoon, evening, night, Sundays, holidays, etc.), thus completing the socio-spatial identity of every neighborhood. Hence, they somehow also contributed to the formation of local social bonds. Furthermore, exhaustive reconstruction with high rise buildings and the prevalence of car-ownership and individual mobility led to a dramatic decrease in public and quasi-public space, and to the formation of diverse urban sound environments, featured, though, by the prevalence of road traffic noise. Thus, important means (space, sounds) of local social bonds were eliminated.

In this context, the case study of an inner-city area of Thessaloniki (Greece) was selected, environmental noise impacts were analyzed and mapped, noise maps were created, and scenarios regarding alterations of the traffic flow and urban form were tested and visualized. The experiment is expected to give answers to the above research questions.

\section{Environmental Noise Pollution in the Mediterranean Metropolis}

The decline of the environmental quality of urban areas is currently a real challenge, due to pollution, non-sustainable development and unplanned growth that could be the cause of rapid changes of both the landscape and the acoustic environment of a city [6]. Environmental noise is one of the major environmental stressors which burden the quality of life and the overall environment. According to the World Health Organization [7], excessive noise exposure can cause mental health effects, hearing problems that prevent speech communication, sleep disturbances and even cardiovascular diseases $[8,9]$.

Especially in southern Euro-Mediterranean metropolises, high environmental noise pollution is a serious and persistent problem, and a downgrading factor of urban life. According to a 2020 EC report [10], South-Eastern European and mostly Mediterranean cities (Bucharest, Palermo, Athens, Istanbul, Sofia, Skopje, Naples, Barcelona, Tirana and 
Valletta), hold the lowest ten scores at the index «People satisfied with the noise level in their city». Similarly, on the 2015 relevant report [11], the lowest scores were held by Istanbul, Bucharest, Palermo, Athens, Sofia, Naples, Greater Athens, Barcelona, Krakow and Lisbon. These public opinion reports correspond to environmental noise research reports for some European-Mediterranean metropolises (Table 1).

Table 1. Percentage of population affected by environmental noise *.

\begin{tabular}{ccc}
\hline City & $\mathbf{L}_{\mathbf{d e n}}>\mathbf{5 5} \mathbf{~ d B ~ ( 2 4 ~ h )}$ & $\mathbf{L}_{\mathbf{n}}>\mathbf{5 0} \mathbf{~ d B}$ (Night) \\
\hline Athens [12] & $99.2 \%$ & $98.3 \%$ \\
\hline Thessaloniki [12] & $97.3 \%$ & $69.0 \%$ \\
\hline Barcelona [13,14] & $85.0 \%$ & $46.8 \%$ \\
\hline Marseille(Agglomeration) [15] & $95.0 \%$ & $37.5 \%$ \\
\hline${ }^{*}$ ) High environmental (i.e., outdoor) noise levels are defined in the 7th Environment Action Programme of the \\
European Environment Agency, as noise levels for $\mathrm{L}_{\mathrm{den}}>55 \mathrm{~dB}$ and for $\mathrm{L}_{\mathrm{n}}>50 \mathrm{~dB}$ [16].
\end{tabular}

Moreover, the major source of environmental noise is road traffic. This is true for the European Union [17], and in particular, Mediterranean Europe. According to measurements in Marseille, about $80 \%$ of urban noise pollution $\left(\mathrm{L}_{\mathrm{den}}\right)$ exceeding $68 \mathrm{~dB}$ is due to road traffic [15]. Examples of country rates for road traffic noise (2012, $\left.\mathrm{L}_{\mathrm{den}}>55 \mathrm{~dB}\right)$ : Spain 60\%, France 55\%, Denmark 47\%, UK 37\%, Germany 24\%) [18].

In combination to the amount of road traffic, the urban fabric features (density, street width, height of buildings etc.) are determinant factors for the intensity of urban noises [19-21]. Consequently, the main cause of this severe urban noise pollution in Euro-Mediterranean metropolises is the combination of road traffic and their urban forms, which have several common or similar urban characteristics; intensive housing, few green areas, lack of infrastructures and services, exploitation of soil to its limits and uninhabitable conditions of some areas, are amongst others, main urban traits of Mediterranean cities, as outlined by Giuseppe Pace [22].

In the volatile economies of south-eastern Europe, home ownership offered the most stable economic security for people, especially for the middle and lower-income classes. As industrial growth was in lack, the main urban and housing policy by governments, such as in Greece, consisted of encouraging the spread of smallholding, in order to promote construction activity, economic growth and maintain social peace [23].

A typical example of this form of urban growth is the urban structure of the inner-city areas of Athens or Thessaloniki, evolved from the interwar period until the early 1980s. Small size of properties and the need to access them from the public space also led to small building blocks and to the waste of public space on an oversupply of roads in order to provide property access [24]. In order to save land, due to the superabundance of streets, their width was limited (usually from 8 to $12 \mathrm{~m}$ ), while road traffic needs also limited the width of most sidewalks (between $70 \mathrm{~cm}$ and $1.5 \mathrm{~m}$ ). In this urban fabric, a massive reconstruction of Athens, Thessaloniki and then other Greek cities evolved after the 50's, through high-rise buildings, high rates of exploitation, frequent transgressions of the legal construction and least free space in private plots.

As in the case of Greek cities, in several Euro-Mediterranean metropolises, waste of public space almost exclusively for street space, and the lack of free spaces on private plots, prevents the inner cities from providing an attractive cityscape and soundscape to their dwellers and visitors. Therefore, the ability to fulfill their needs for a vital and healthy environment, suitable for living, working, walking, relaxing, cycling, etc. was hindered.

Moreover, the shortage of free and attractive public space further affects the quality of life, as in Mediterranean cities, due to climatic conditions; most forms of human activities are mainly conducted outdoors. The prevalence of such conditions, in the inner-city areas of Mediterranean Metropolises of Europe, provokes a lasting movement of their dynamic strata in the suburbs, and the acceleration of urban degradation, that undergo the lower strata remaining or replacing the population losses. Some analyses [25] describe, more or 
less, the emergence of this new form of urbanization, which is the result of the freedom of choice in every aspect of individuals' life, as the single prospect of urban development, while pointing out the crucial questions posed regarding the sustainability of this model. Indeed, dispersed urbanization form entails very extensive infrastructure and public service needs, as well as an immense waste of countryside, farmland and of other resources. In short, it is not rational nor realistic to let an entire country turn into a quasi-urban region.

Contrariwise, a compact city model, based on the principles of design excellence, social well-being and environmental responsibility [26] is a perspective, adopted by UN [27] OECD [28] and the EU $[29,30]$ as a sustainable answer to the question of the role of cities and of urban growth in the 21st century. This point of view also recognizes that compact cities, and more specifically their centers, are the nuclei of post-industrial economy, and a key element for every country, to take part in the global networks of economic growth [23].

According to this viewpoint, also shared by the EU institutions [31], the aim of actions to improve urban space should be oriented to city-center and inner-city areas, which are seriously suffering from degradation, as they are massively deserted by the middle classes and dynamic economic activities moving to the suburbs. In this context, the improvement of urban space in extended inner-city areas, including the creation of quieter and better soundscapes, will enable the simultaneous improvement of private and public spaces. This poses as a key stake for the territorial and social cohesion [32] and for a sustainable quality of life in Euro-Mediterranean cities.

\section{Theoretical Viewpoints}

\subsection{City as a Palimpsest}

As mentioned by Bailey, geographers and archeologists consider the so-called "palimpsest landscapes", referring to the locations where landforms of different geologic ages shape a contemporary site [33]. Under this consideration, cities are multilayered, and therefore the physical elements of the past are covered by modern urban structures [34].

A palimpsest is defined as a manuscript on which older text have been partially erased in order for new text layers to be placed. Over time and over layer application, past writings can still be identified [35]. The term palimpsest has been used as a metaphor on several occasions [36].

The city and its territory are similar to a parchment, metamorphosed by the action of nature and humans, and endowed over the centuries with diverse meanings in relation to the societies that transform them, without effacing the marks of time, both natural and anthropical. The layers that appear today, superimposable in urban fabrics and in their territories, represent for our society a legacy not to be removed, but, indeed, to be recognized and enhanced. In addition, Aldo Rossi [3] reminds us that history and shared memory, composition and superimposition, coherence and divergence are fundamental conditions of the city as we know it. The city appears as a palimpsest of interventions of all natures. It is thus evident that Smart cities as a rather new urban ideal and also a disruptive innovation process cannot be conceived nor implemented, all at once; they must follow analogous processes of stratification and buildup.

\subsection{The Urban Acoustic Palimpsest}

The term soundmark introduced by M Schaffer [37] refers to the culturally significant sounds of a place, such as church bells or town square clocks [38]. Soundmarks, like landmarks, are "iconic" and directly associated with a place. Furthermore, they are considered vital in soundscape description [39]. Apart from soundmarks, other significant sound signals [40] of biological, geophysical and anthropogenic origins are often audible in an acoustic environment. Bernie Krause [41] noted that in order for an orchestra to function, each instrument must have its own unique voice. Similarly, in order for an acoustic environment to function, all its soundmarks and sound signals of biological, geophysical and anthropogenic origin need their own unique place. Each organism has its own sonic niche or place in the frequency spectrum occupied by no other at that particular moment [42]. 
The acoustic niche hypothesis supports that each species evolves to establish and maintain its own acoustic bandwidth, so that its voice is not masked [43].

The increased noise levels of urban environments have hindered the audibility of soundmarks [38,44], by occupying the acoustic niche of sound signals, resulting in an alteration of the acoustic identity of a place in a city. In present day, urban landscapes and therefore soundscapes are composed by layers of structural and aural information. Evidence of this geological and aural stratification is the assessment of historical landmarks that are present in an elevation below street level [45], creating in an allegorical way, an acoustic palimpsest.

An analogy can be shaped using the term palimpsest, devised by the fact that soundmarks and sound signals are covered or else masked by noise [46]. This phenomenon can be described as an urban acoustic palimpsest in time, space [47] and spectrum. A spectrogram could be viewed as a visual representation of an acoustic palimpsest. Spectrograms are divided by frequency bands [48] and each one can be associated with a different landform layer.

By disengaging the lower frequency spectrum in an acoustic environment usually occupied by road traffic noise, additional sonic niches will be available. As a result, the acoustic environment will be enriched, offering numerous benefits in both cultural and natural heritage restoration. The use of autonomous electric vehicles (AVs) could benefit the acoustic conditions of a city by substantially lowering the noise levels deriving from traffic [49]. Nevertheless, cities need to adjust in these new standards, regarding the necessary actions that need to be taken, and supported by a broad portfolio of financial and policy-related benefits [50]. Among the benefits that could probably derive with the introduction of autonomous vehicles (AVs) are safer roads, less congestion, alterations in travel behavior, including parking patterns, long distance traveling with no drivers, and several economic impacts [51]. Nevertheless, policies regarding their implementation could possibly deal with several barriers [52] in relation to the vehicle cost, the certification needed in relation to the active legislation of a country, the liability regarding the decisions made (or not) without the driver's participation, the security from various hazards similar to cyber-attacks, and finally the privacy factor, due to the possibility of data sharing regarding optimized routes taken by AVs users. These data could be misused for tracking individuals in order to provide law enforcement agencies with information [51]. Finally, AVs can be incorporated in noise modeling. Noise modeling is a way of linking theory to experimental design in order to conduct research, thus simplifying a real situation and enabling the development and testing of predictions. In order to introduce AVs into a noise prediction model, knowledge regarding the sound power level emitted by electric vehicles is necessary [53].

Conventional vehicles occupy mostly the lower frequency bands [54] by emitting low frequency noise [8]. The spectral analysis on EVs highlighted the similarities and differences with the spectral properties of conventional vehicles. Even though there is little difference on the lower frequency bands among the two types of vehicles, conventional vehicle sound can reach a higher frequency range (up to 16,000 Hz) [55]. Therefore, the use of EVs and AVs could possibly "liberate" a wide frequency range, returning the acoustic niche to its original inhabitant. Nevertheless, more research on the matter is necessary due to the fact that several parameters similar to vehicle speed and category (light or heavy) significantly influence both the frequency range occupied and the sound pressure levels $[55,56]$.

Acceleration and braking conditions increase the overall sound emission of all vehicle types. It was concluded that by doubling the speed, the emitted noise is increased by 9 to $12 \mathrm{~dB}(\mathrm{~A})$ and that there is not a considerable difference above $40 \mathrm{~km} / \mathrm{h}$. The noise emitted by electric vehicles is calculated by removing propulsion noise [49], but still, all evidence leads to the fact that vehicle speed plays a very important role in the noise outcome. Nevertheless, a correction coefficient of $-15 \mathrm{~dB}(\mathrm{~A})$ that regards the removal of propulsion noise for electric vehicles is provided [56] and a reduction of $2 \mathrm{~dB}(\mathrm{~A})$ for the total noise 
produced [57]. These correction coefficients are the result of several modeling techniques that aim towards a better understanding regarding the difficult task of EVs incorporation in road traffic noise prediction.

\subsection{The Effect of Urban Form}

Urban form is extremely important for regulating environmental noise. Noise propagation is substantially influenced by the morphology of urban settlements, in different urban textures [58]. The arrangement and shape of buildings, along with their irregular structural features, may enable the attenuation of environmental noise [59]. Furthermore, recent research associated urban quietness with urban green areas, emphasizing the strong relationship between quietness and biodiversity $[60,61]$. Urban green areas provide ecosystem services to urban dwellers with numerous environmental and social benefits [62]. Some of the benefits credited to urban green areas [63] are air infiltration, improvement of microclimatic conditions, creation of recreational and cultural values, hydrological services, biodiversity enrichment, and noise mitigation $[10,64]$. The presence of green areas in urban settlements can also protect its residents from environmental noise [65]. Green roofs and green vertical walls also present an important noise attenuation effect [66]. Moreover, significant qualities of urban green areas address adaptation capabilities [67], such as accessibility, quantity and quality. Urban green is also an essential shelter for biodiversity [68], given the deprivation of rural habitats caused by unsustainable agricultural practices [69,70].

An important issue in the urban tissue towards the improvement of the acoustic environment is ecological connectivity. The goal of ecological connectivity [71] is meant as perceiving urban areas not as independent units, but as disconnected patches in need of reconnection within the urban environment [72]. This also stands as one of the underpinning principles of the concept of green infrastructure. Green infrastructure planning includes physical and functional connections between green spaces at different scales and from different perspectives [73].

Another issue of paramount importance is the biological [74] and cultural complexity [75] that, under an acoustic prism, are of vital importance for both a healthy and a culturally rich environment. Regarding biological complexity, advancements in the field of ecoacoustics [76] has provided the necessary tools of assessment. The Acoustic Complexity Index (ACI) is based on the observation that biotic sounds, such as birdsongs, have an inherent complexity and are characterized by a variability of intensities, while anthropogenic sounds, such as road traffic noise, have constant intensity values. This index calculates the number of large peaks in terms of intensity in a spectrogram $[77,78]$.

On the matter of cultural complexity, anthropological research could aid the procedure of its assessment. The effects of demography on cultural complexity are well documented. A smaller population, meaning a reduced number of individuals that are able to interact, deals with a loss of cultural complexity [79]. The loss of connectivity [71] in an urban environment can be the cause of isolation in an acoustically homogenized, un-eventful acoustic environment. The aforementioned homogenization can be the result of the occupation of the lower frequency spectrum due to noise emitted by road traffic noise. Biological diversity and cultural diversity are interconnected and communicated as biocultural diversity [80]. Biocultural homogenization poses as a threat and the need for biocultural conservation in terms of socio-environmental justice is undeniable [81]. At this point, the authors of this research draw attention to the spectral dimension of sound emission by AVs and EVs, in order to highlight the drivers, added-values, barriers and impacts on biocultural complexity - the pros and cons of the incorporation of AVs and EVs in urban mobility. Through an environmental scanning technique [82], indicative insights of a group of post-graduate students were captured and are presented in the following Table 2. 
Table 2. Incorporation of AVs and EVs in urban mobility, Pros and Cons.

\begin{tabular}{|c|c|}
\hline Drivers & Barriers \\
\hline $\begin{array}{c}\text { Lower noise emission levels } \\
\text { Reduced vehicle movements in search of a parking plot } \\
\text { Improvement of travel safety } \\
\text { Better accessibility } \\
\text { Increase in capacity of the existing transport infrastructure }\end{array}$ & $\begin{array}{l}\text { No significant difference regarding noise levels, when the speed } \\
\text { of the vehicle is higher than } 50 \mathrm{~km} / \mathrm{h} \text {. }\end{array}$ \\
\hline Added-values & Impacts \\
\hline $\begin{array}{l}\text { Enhancement of the bio-cultural complexity/diversity through } \\
\text { replacement of parking plots with green spaces. }\end{array}$ & Possible lower band spectrum occupation \\
\hline Positive effects on urban form & $\begin{array}{l}\text { Possible biocultural complexity hinderingIncrease in road } \\
\text { traffic noise }\end{array}$ \\
\hline Green infrastructure opportunities & Increase in traffic due to individual travelling conditions \\
\hline Car pooling & Increase in road traffic noise \\
\hline Restriction/abolishment of private car ownership & $\begin{array}{l}\text { Green gentrification after replacement of parking plots with } \\
\text { green spaces }\end{array}$ \\
\hline
\end{tabular}

Source: Own elaboration by authors after a brainstorming with post-graduate students of the Department of Economic and Regional Development, Panteion University.

\subsection{Drafting Narratives of Mediterranean Inner-City Areas Transformation}

As already argued, an important goal for the improvement of urban life quality in the inner-city areas of Euro-Mediterranean metropolises should be the creation of quieter and better acoustic environments, that will be able to improve acoustic conditions of interiors, exteriors and public spaces simultaneously.

The drastic reduction of motorized road traffic, which is the major source of annoyance, should be the primary goal of this attempt. Road traffic is the effect of vehicle mobility for both transportation and parking purposes, the latter being an important factor of traffic surcharge in urban cores or inner-city areas [83,84]. In the case of inner-city areas of Euro-Mediterranean metropolises, demand for on-street parking is high, as most buildings do not offer parking lots. For example, in Greece, until 1979, there was no obligation for new buildings to include parking lots; but then the reconstruction of inner-city areas was almost complete. A research conducted in two Athenian inner-city neighborhoods, found that only $10 \%$ of buildings were constructed after the beginning of $80 \mathrm{~s}$, that is after the issue of the obligation to include parking lots [85]. Therefore, for the purpose of reducing road traffic and its negative effects [86], an additional goal should regard efforts to reduce or eliminate vehicle movements in search of a parking place or space. However, in the case of Euro-Mediterranean inner cities, there are major obstacles to achieve these goals. The occasional lack of good quality transport services encourages the use of private cars amplifying road traffic, whilst the small size of properties and the lack of empty plots does not allow the creation of parking lots in existing buildings, nor the construction of new buildings incorporating parking lots.

An overall answer to this question is given by the strategy adopted by the EU in recent decades: "to set priority to more sustainable forms of transport-public transport, pedestrians and cyclists, by eliminating road space from private cars" [87]. The creation of pedestrian street networks, mostly in historic cores, is the most common urban planning answer, along with the experimental implementation of the idea of car-free cities. Of course, in these cases, moving is a matter of walking, cycling or using public transport means, which are the most sustainable ways of mobility. However, the use of private car remains for some citizens a necessity; depriving them of car use would lead to serious inequalities. For instance, people with reduced mobility problems, women who usually take care of children or the elderly, and / or move at night, need a private car in order to be able to move freely and safely [88]. Moreover, during the COVID-19 pandemic, the use of public transport and shared mobility services declined dramatically, whilst citizens 
favor(ed) private vehicles, such as cars and bicycles, and also walking. Hence, the need for individual auto-mobility cannot disappear.

As these issues become more acute, technological progress adumbrates major changes in urban space and city functions and life. The emerging 4th industrial revolution, characterized by a shift from instruction-driven computing to data-driven computing [89], brings a series of new technologies (electric vehicles-EVs, renewable energy systems-RES, ultrafast telecommunications 5G, internet of things-IoT, robotics, autonomous vehicles-AVs), leading to speculation about their future influence on city forms, living conditions and urban growth. The contribution of electric vehicles (EVs) to decreasing air pollution and greenhouse gas emissions, both on local and planetary scale, could be major, if they were fueled by electric energy, coming from renewable sources (RES). However, the prevalence of EVs in city transports by itself is not expected to considerably improve noise conditions in urban environments, as their contribution to the field of noise reduction is forecast rather weak [53].

Ultra-fast telecommunications (5G), the internet of things (IoT) and robotics are the main technologies that enable the development of AVs, which are expected to reach a stage of maturity in less than 10 years. Besides, driving automation of AVs (Self driving cars) [86] is classified in levels 0: No automation, 1: Driver assistance, 2: Partial automation, 3: Conditional automation, 4: High automation, and 5: Full automation. A fully AV in the 5th level is expected to be commercialized about 2030 and will use many advanced technologies. It is expected to be non-polluting (electric-driven), perceive continuously its immediate traffic environment, follow traffic rules and instructions, collaborate and interact with other vehicles and pedestrians, be able to receive and elaborate information and choose routes to avoid congestion, so as to make its movement safe and optimum for the urban function and its passengers [90-92]. According to many predictions, the impact of AVs following their exclusive prevalence, after they acquire a full autonomy (level 5), is expected to have some clear positive effects: a spectacular improvement of travel safety by the quasi-elimination of traffic accidents [93], a better accessibility in mobility for disabled, elderly, children $[86,94]$ and a considerable increase in the capacity of the existing transport infrastructure [95].

\section{Materials and Methods}

\subsection{The Case Study Area}

The site chosen for the calculation of road traffic noise is a $30.000 \mathrm{~m}^{2}$ densely built urban area (Figure 1) located in the eastern part of Thessaloniki, which is the second biggest city of Greece.

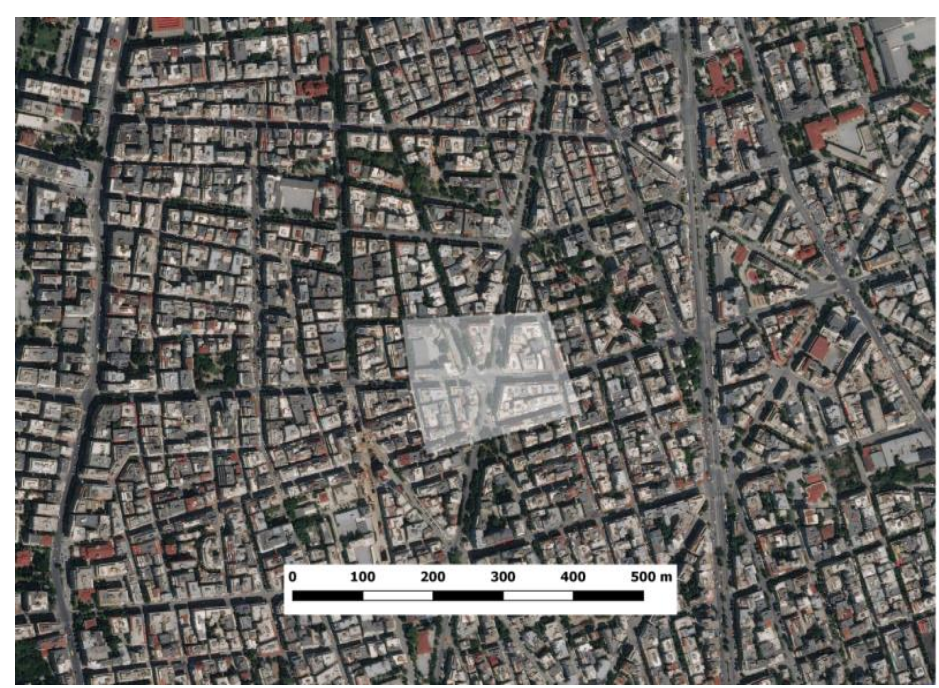

Figure 1. The case study area located in the eastern part of the city of Thessaloniki. 
The specific area was chosen due to the high population density, the dense urban fabric with high-rise buildings, high rates of exploitation, frequent transgressions of the legal construction and least free space in private plots. In addition, it was ideal for the experiment due to the fact that it includes one of the most frequently used major roads (Botsari street) of Thessaloniki. This specific road very often faces heavy congestion due to the illegal parking lots. Furthermore, it is connected to several narrower local roads that are facing similar complications.

\subsection{Noise Mapping Data Collection}

Noise maps were created in order to visualize the propagation of road traffic noise. The specific type of anthropophony has always been a major source of annoyance in urban environments $(\mathrm{Ow})$, while numerous efforts for its reduction have been tested with various results. Information regarding road traffic noise derived from traffic flow records, vehicle speed and road surface quality data. Noise maps were created using the geographic information system mapping technology (GiS) software and the CadnaA noise prediction software, which is used for the calculation, presentation, assessment and prediction of environmental noise. Structural morphology data were collected and imported to CadnaA software (DataKustik), along with traffic flow data. More specifically, the following were collected:

- Detailed cartographic representation of the area under consideration (buildings, roads, vegetation);

- Building height and exact location;

- Vegetation height and exact location;

- Road type classification (Motorway, Ordinary Road, Local);

- Type of road surface (smooth/rough);

- $\quad$ Speed limitation;

- Traffic lights location and operation.

Alterations regarding the above information could lead to different outcomes regarding the acoustic conditions of an area, thus allowing strategy plans regarding noise reduction to take place. Furthermore, the collection of data regarding the noise emission of different types of vehicles could also differentiate the final outcome of a noise map.

The data collection procedure involved manual traffic volume counts in one check spot (Figure 2) that served as a panopticon for all roads in the area under consideration. More specifically, four roads were assessed, two of which were major roads and two local roads. For five consecutive days (28 March-1 April), traffic volume was counted using three vehicle category types (Cars, Bikes, Heavy vehicles) for one hour at three periods (Day period: 11:00-12:00, Evening period: 19:00-20:00 and Night period: 23:00-24:00).

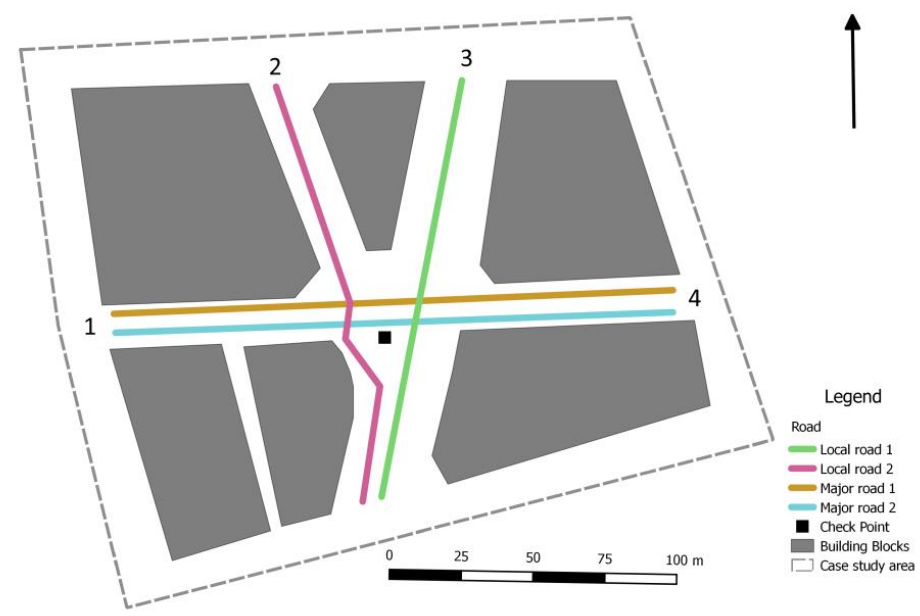

Figure 2. Case study area including the road classification and the check spot used for traffic volume data collection. 
Furthermore, two scenarios were tested in order to assess the effects of road traffic on the overall acoustic environment. The first one regarded a vehicle speed decrease from $50 \mathrm{~km} / \mathrm{h}$ to $30 \mathrm{~km} / \mathrm{h}$. The second one regarded the application of the correction coefficient for the total noise produced provided for electric vehicles, which is limited to about $-2 \mathrm{~dB}(\mathrm{~A})$.

\section{Results of the Experiment}

\subsection{Traffic Count Data Results}

The traffic count data for the five days of the observation period are presented in the Annex (Figures A1-A5). Due to COVID-19 restrictions, mobility during the night period is prohibited and limited to only for work related purposes. Therefore, a dramatic increase in traffic volume is observed during the night period with small numbers of bikes and cars. Figure A1 shows the traffic count data of the first day of the observation period. Figure A2 presents the traffic count data for the second day of observations, Figure A3 for the third day, Figure A4 for the fourth day, and finally, Figure A5, presents the traffic count data for the fifth day of observations.

\subsection{Noise Mapping Results}

Five noise maps were created, one for every day of data collection. The height of the surrounding buildings was measured $( \pm 20 \mathrm{~m})$ and the quality of the roads was visually assessed (smooth asphalt). The speed limitation used for the calculations was the one imposed by the local authorities, which is $50 \mathrm{~km} / \mathrm{h}$. This information was included in the noise propagation calculations, along with the traffic flow data for each road for the day, evening and night period. The noise maps present little to no difference regarding noise propagation due to the very similar outcomes regarding traffic volume (Figure 3).

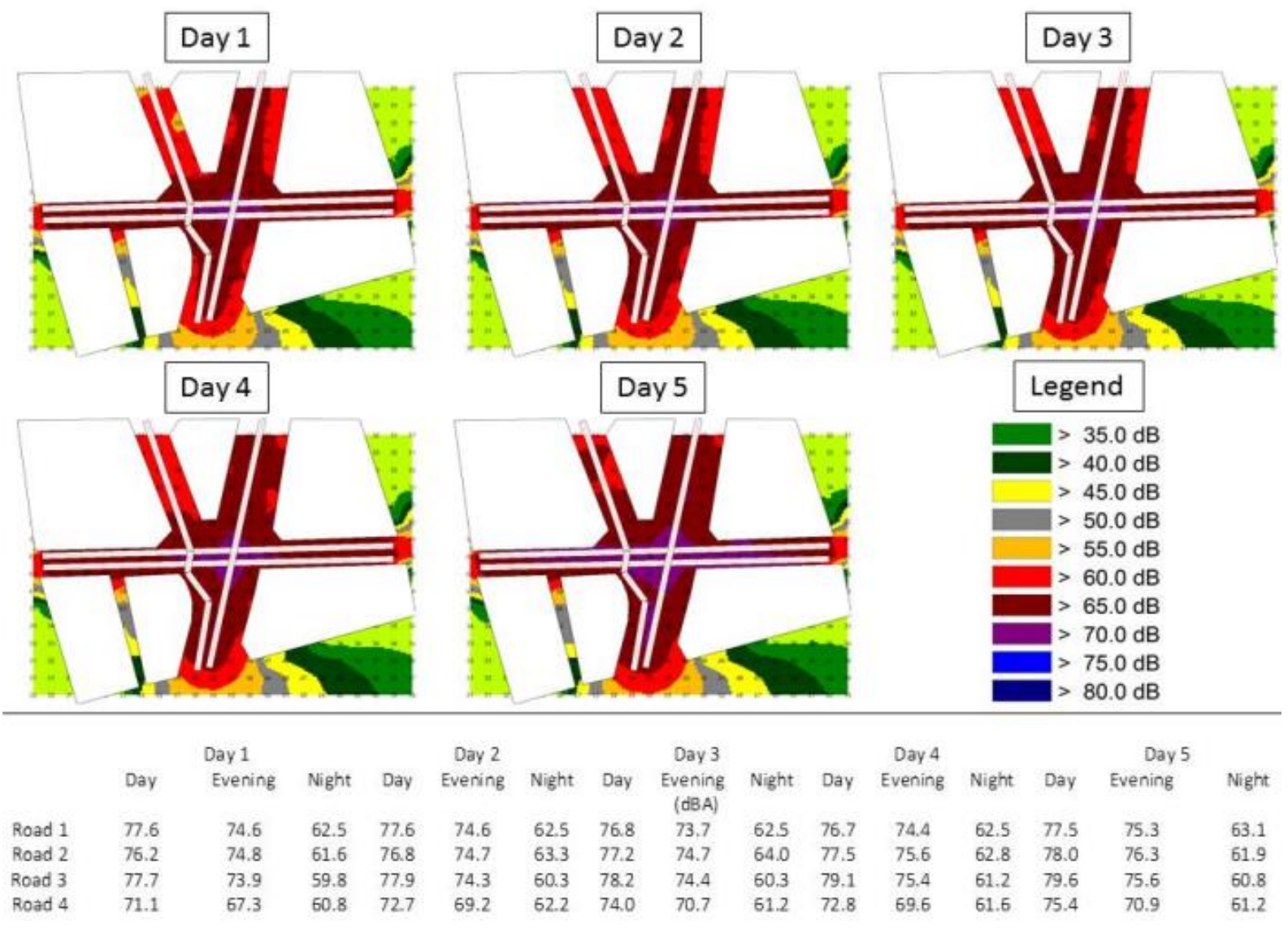

Figure 3. Noise maps for the five-day period of data collection. 


\subsection{Scenarios' Results}

Two different scenarios were tested for this research. The noise map representing the current condition is presented in Figure 4. The first scenario regarded a vehicle speed decrease from $50 \mathrm{~km} / \mathrm{h}$ to $30 \mathrm{~km} / \mathrm{h}$ using the mean value of the vehicle volume during the 5 data collection days (Figure 5). The second one regarded the application of the correction coefficient provided for electric vehicles, which is limited to $-2 \mathrm{~dB}(\mathrm{~A})$ along with the speed limit reduction to $30 \mathrm{~km} / \mathrm{h}$ (Figure 6).

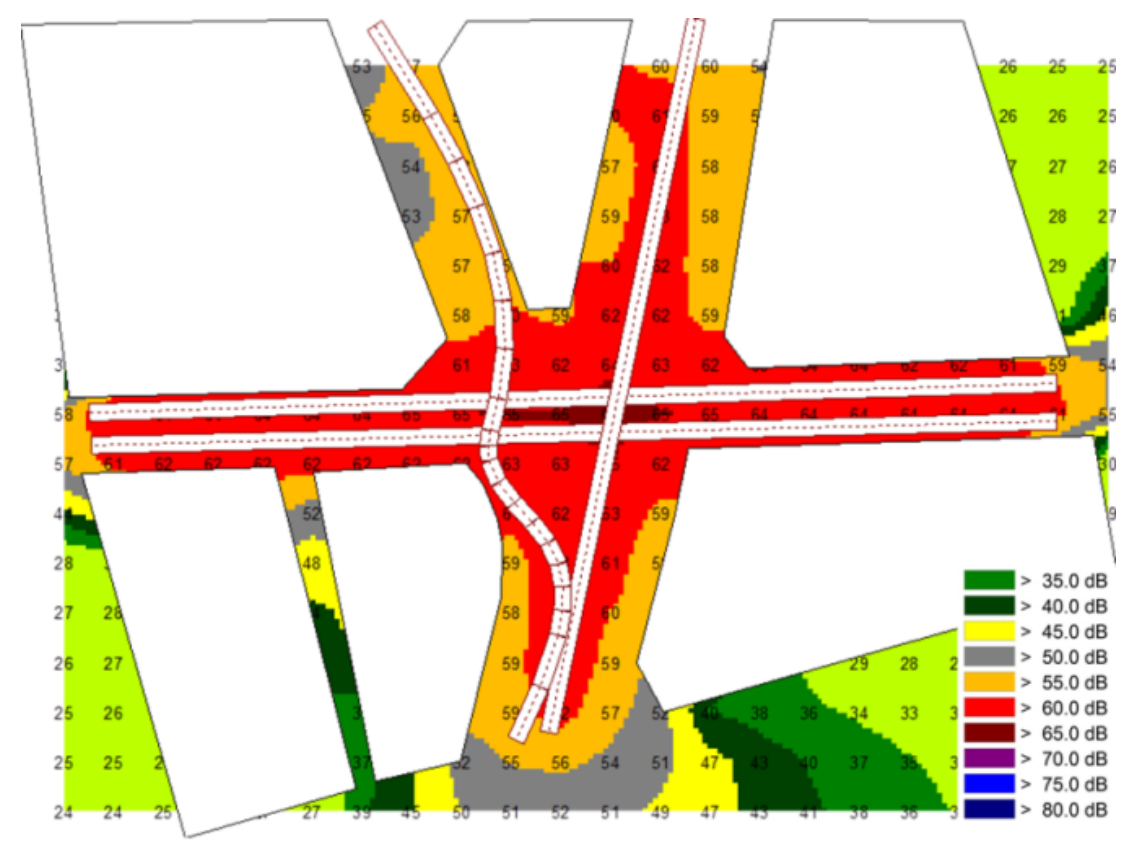

Figure 4. Noise map for mean traffic volume at $50 \mathrm{~km} / \mathrm{h}$.

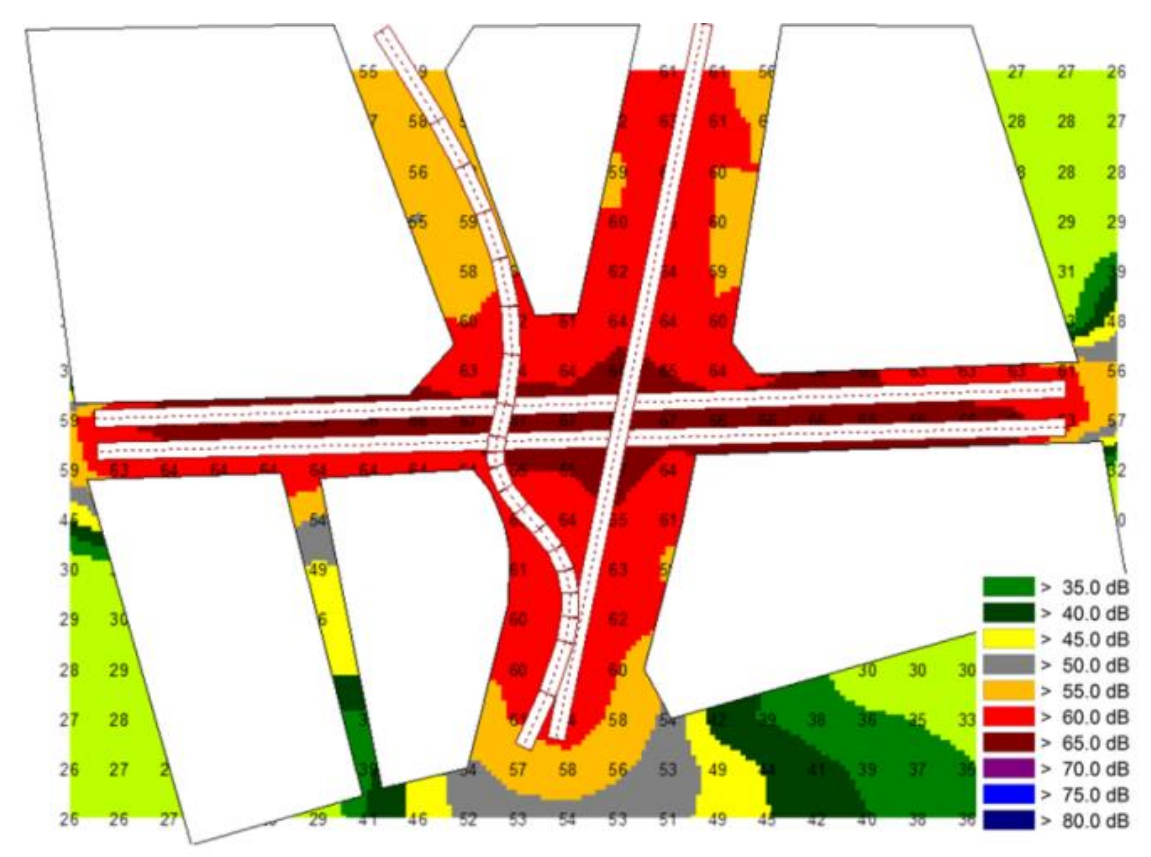

Figure 5. Noise map for mean traffic volume at $30 \mathrm{~km} / \mathrm{h}$. 


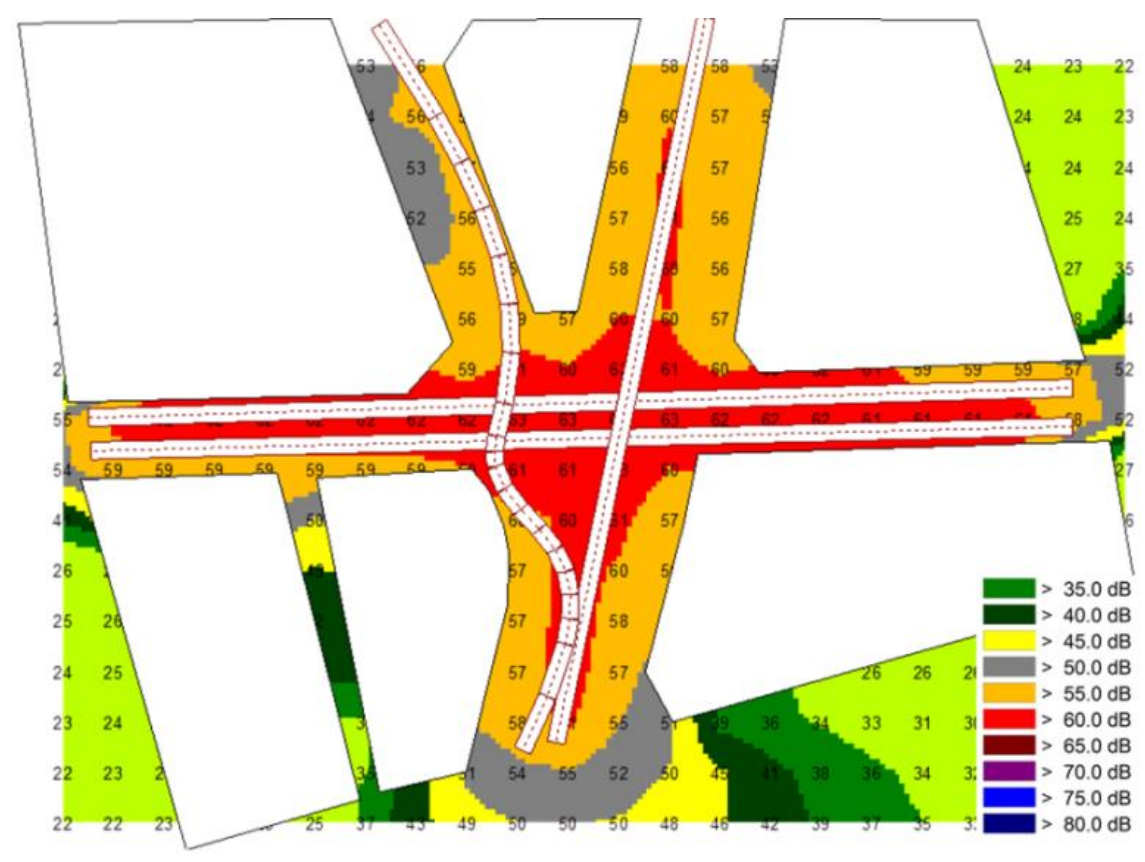

Figure 6. Noise map for the mean traffic volume at $30 \mathrm{~km} / \mathrm{h}$, along with the correction coefficient of $2 \mathrm{~dB}$ attributed to EVs.

A major issue that regards noise modeling in this case is the homogeneity of the data imported. A uniformity of driving speed, either high or low, is not expected, while the differentiations regarding driving habits cannot be modeled due to software limitations. Furthermore, the braking and acceleration driving states that play a very important role in the environmental noise produced are also not included in the calculations. The speed reduction to $30 \mathrm{~km} / \mathrm{h}$ alone did not affect the noise map outcome (Figure 5). This result derived probably due to the software modeling assumptions. The existence of a street junction with 4 traffic lights and different type of roads, interpreted the low-speed vehicle movement as a traffic jam. The engines of numerous conventional vehicles at lower speeds, given the continuous braking and acceleration of the vehicles, could produce more noise than a steady traffic flow. Nevertheless, the reduction of the vehicle total noise emission to $-2 \mathrm{~dB}(\mathrm{~A})$ along with a speed limitation at $30 \mathrm{~km} / \mathrm{h}$ contributed to the creation of an acoustic environment with decreased noise levels (Figure 6).

\section{Discussion}

The hypothesis of introducing spatialized intelligence in the Mediterranean inner-city areas, combined with the experiment in a Mediterranean city with dense urban fabric, has led to the following two diverse key narratives, with the implementation of each of them leading to completely different effects [96,97].

According to the first-negative-narrative, AVs would just replace conventional vehicles in an unchanged context of mobility ways and behaviors, featured by the predominance of individual mobility and the abundance of privately owned cars. In this case, the overall improvement of individual traveling conditions would result to a continuous increase in traffic $[91,97,98]$ and to the seek for parking lots, and thus, among other negative effects, the increase in road traffic noise.

The second narrative outlines a positive change, driven by the principles of sustainability [98], social responsibility and equity [99], aiming to support social cohesion [100] and urban development strategies [101]. In the variant versions of this narrative, the emphasis is on predominantly public [97] or shared AVs [86,96,100], in a perspective of a rational programming of urban mobility, complemented by soft mobility (walking, cycling etc.) and combined in a hybrid transport system, which should be based on: 
1. Autonomous shuttle buses, complementary to metro and tramway systems. AV technology in public transport is expected to be highly efficient [102].

2. Car-pooling, car-sharing and car-on-demand systems, which could come from peripheral parking and recharging areas, to serve all inner-city people in need of an individual ride, as a complement to mass public transport [103].

3. Autonomous light electric vehicles (motorcycles, bicycles, skates, etc.), to serve short distance trips, as well as on the promotion of walking.

Thus, a main idea in this narrative is the containment of traffic by means of rational and sustainable use of technologies and transport infrastructures, leading also to the mitigation of road traffic noise. Another important idea that could be included in the above positive narrative is the restriction, even the abolishment of private car ownership, by taking advantage of car-pooling, car-sharing and car-on-demand systems. A major change like this, is feasible as 5th level AVs will be able to be commanded to start from the closest parking area, lift up passengers from concrete addresses, drive them to their near or farthest destinations, and then access the closest parking area, to stand-by and be recharged. This feature of AVs would allow people in need of individual rides to move freely and in safe; yet the offer of a high quality and affordable public transport system would be necessary, in purpose to avoid a wide spreading of individual auto-mobility and of subsequent negative effects (congestion, pollution, noise).

Likewise, this idea of abolishment of private car ownership starting from city cores and inner-city neighborhoods, seems to gain ground in politicians' think-tanks and public opinion. For instance, the Parliament Science and Technology Committee of UK [104] claimed (2019) that in the long-term, car ownership is not compatible with decarbonization goals, rejecting the policies encouraging people to replace existing vehicles with loweremission versions.

Moreover, although the abolition of private cars should be rather a very long process, due to consolidated new settlement patterns and reformed consumption and production geographies [105], many press publications see the time of a mass abandon of car society as approaching: By expressing a positive argumentation for this objective, especially about inner-city areas; by pointing out the proliferation of car-free lifestyle by wealthy people $[96,101,106]$ and of the enactment of restrictions for cars in several city centers and inner-city areas [107] implying that emancipation from private cars is feasible; and by the speculation that autonomous cars are going to change the way people feel about car ownership [101]. A prospect of AVs spread and of car ownership abolition also leads probably to the elimination of on-street parking (parking lots), liberating an important amount of public space $[103,108]$. Such a scenario may definitely lead to free-up the narrow streets of Mediterranean metropolis cores and inner-city neighborhoods from on-street parking, providing space and accessibility to pedestrians and cyclists, enabling the creation of green spaces, recreation/rest areas and street equipment.

This opportunity for the Mediterranean metropolis, severely suffering of lack of vital public space, is also an opportunity to improve their environmental noise conditions. Abolition of on-street parking lots may probably lead to an important decrease in road traffic, as additional traffic of cars seeking for parking places would be eliminated. In addition, filling in the space occupied by parking lots with vegetation and green lanes (trees etc.) would enhance sound absorption, further decreasing the environmental noise levels. The increase of green areas in the city will improve ecosystem health, thus naturally promoting a balanced acoustic environment, leading to a pleasant soundscape. The emergence of biophony due to the increase of green areas, among other benefits, will replace unwanted sounds and will probably play a subtle masking role to environmental noise. Removing the parking spaces (some of which may be relocated to underground lots) will create free space for trees, wider sidewalks, pedestrians and cyclists.

According to the scenarios tested, speed limitations up to $30 \mathrm{~km} / \mathrm{h}$, along with the incorporation of $\mathrm{AVs}$, could substantially benefit the overall acoustic environment. Nevertheless, there are still major limitations and shortcomings that need to be evaluated 
and assessed before this kind of implementation. A regulated vehicle volume also contributes to a quieter acoustic environment but still road traffic noise is not the only source of environmental noise in an urban settlement.

\section{Conclusions}

The limitation of our research is that noise maps created regard solely the noise produced by road traffic. However, other types of anthropophony also play a very important role in the overall acoustic conditions of a city. EVs (and AVs) produce less noise than conventional vehicles, but this regards mainly the propulsion noise emitted. As previously stated, the prevalence of EVs alone will not considerably improve noise conditions, due to the rolling noise contributing to the total noise produced, and the necessity for EVs to use warning sounds to ensure the security of pedestrians. Hence, there is a fuzziness regarding noise issues in an agglomeration, and a multi-leveled approach will be necessary. Therefore, further research must follow a complete noise modeling approach incorporating several noise sources along with road traffic noise. This can result to a better representation of the urban acoustic environment, thus allowing for holistic action plans to take place.

In any case, first of all, environmental awareness stands as the key towards the solution regarding noise problems. Driving habits mainly through speed limitation, along with a regulated incorporation of AVs, could result in a healthier acoustic environment. It is undeniable that AVs reaching the 5th (full) level of automation could offer multiple benefits on the overall environmental quality, including air pollution reduction. Additionally, AVs will offer opportunities of significant reduction on environmental noise levels if their implementation complies with urban design strategies driven by the principles of sustainability, social responsibility and equity.

As already explained, the combination of the future predominance of AVs with a narrative of abolishment of private car ownership and of the need for on-street parking in the inner-city areas could lead to largely enhance public spaces and to decrease road traffic noise in their neighborhoods.

All these changes could provoke dynamics for a renaissance of the traditional Mediterranean culture for outdoor life, also revealing and expanding the formation of mild and intimate sound environments, composed mainly by sounds of human activities and contacts, of nature, and of urban flora and fauna, reactivating hence some positive dimensions of the urban heritage of Mediterranean cities. This is particularly applicable in the historic cores of these cities, and special measures should be adopted to promote sustainable modes of transport and reduce the invasion of conventional vehicles in these areas.

Summing up, we could conclude that spatialized intelligence can substantially and positively transform the sound identity of the Mediterranean metropolis and be the spearhead for an increase in acoustic bio-cultural diversity. At least during the era when the city still appears as a palimpsest of interpositions, evoking the historic time.

The focus of this paper is to portray the complexity of urban and sound design of cities, and specifically of the Euro-Mediterranean ones, in the 21st century. In this context, the many challenges of sound design of urban space require that acoustic engineers and sound designers become more collaborative to other disciplines, like urban planners. Planners need sound designers for guidance in order not to ignore sound identity issues in urban planning, and sound designers need to be prepared to provide such assistance in a collaborative way. This will allow a more holistic consideration of the urban transformations, also considering the wider environmental, economic, social and cultural effects of spatialized intelligence.

Author Contributions: All authors have contributed equally to this work. All authors have read and agreed to the published version of the manuscript.

Funding: This research received no external funding.

Data Availability Statement: All data generated are original, based on the experiment conducted. 
Acknowledgments: The authors would like to warmly thank the three anonymous reviewers for their constructive comments. They also thank the post-graduate students of the Department of Economic and Regional Development of Panteion University for their insights on the effects of incorporating AVs in urban mobility.

Conflicts of Interest: The authors declare no conflict of interest.

\section{Appendix A}

Figures on traffic count data from the 5 days of the data collection procedure.

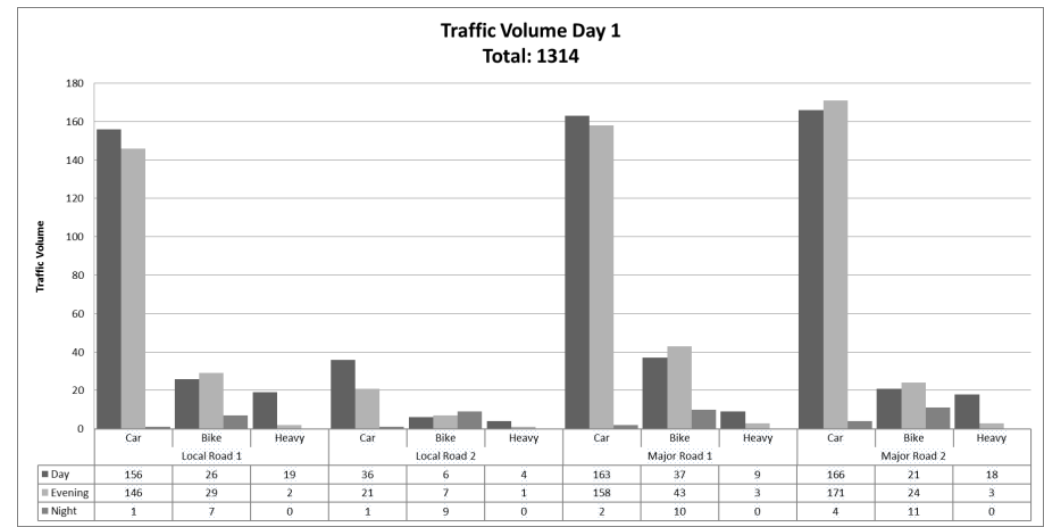

Figure A1. Traffic count data from the first day of the data collection procedure.

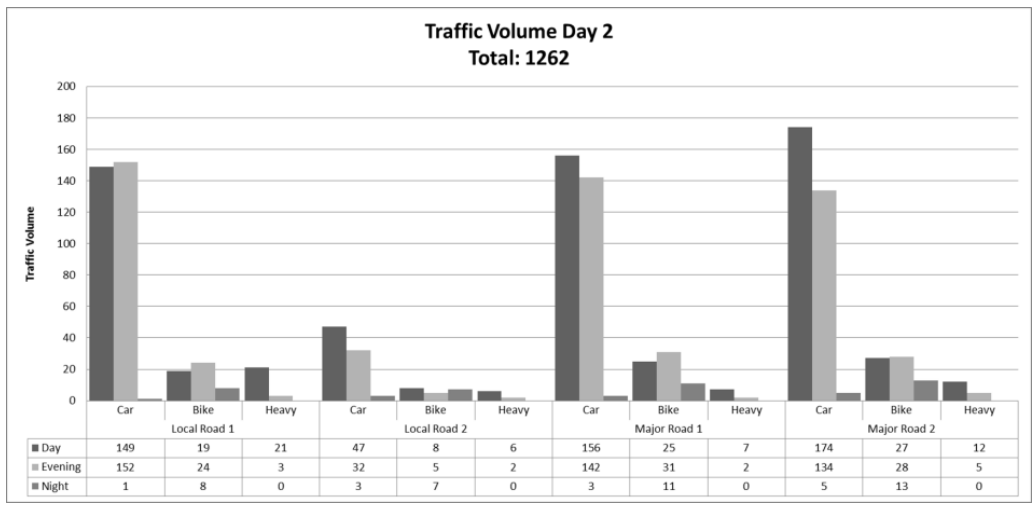

Figure A2. Traffic count data from the second day of the data collection procedure.

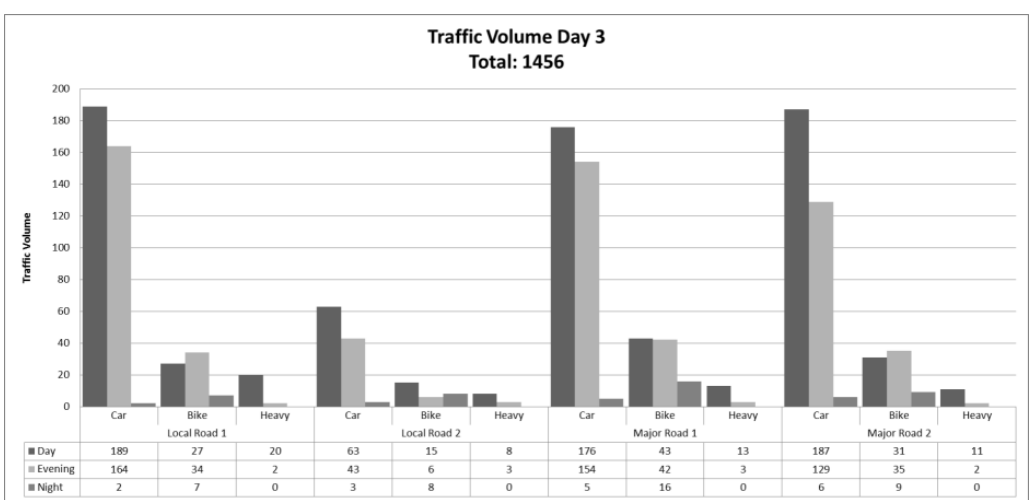

Figure A3. Traffic count data from the third day of the data collection procedure. 


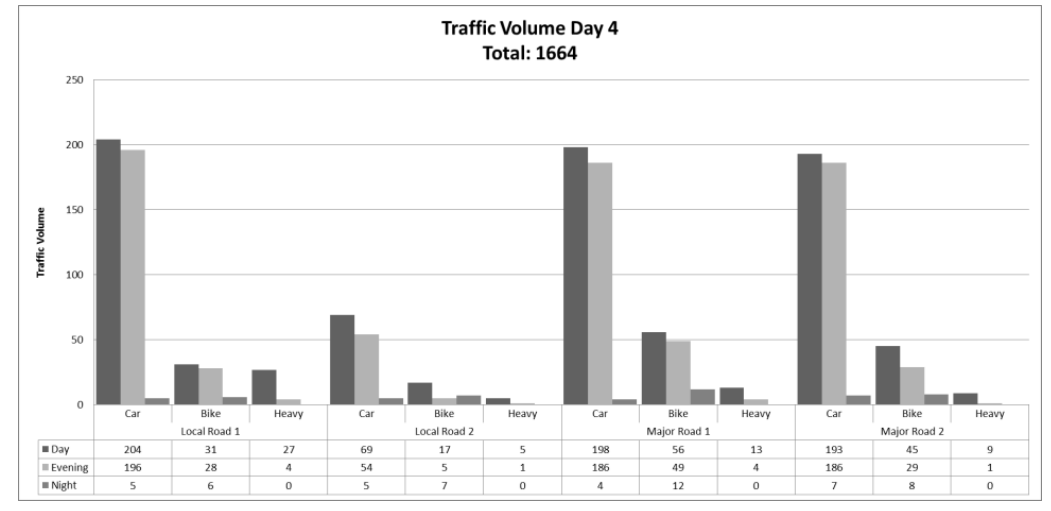

Figure A4. Traffic count data from the fourth day of the data collection procedure.



Figure A5. Traffic count data from the fifth day of the data collection procedure.

\section{References}

1. $\quad$ Picon, A. Smart Cities: A Spatialised Intelligence; Wiley: New York, NY, USA, 2015; ISBN 978-1-119-07559-2.

2. Kyvelou, S. The Urban Question in the Context of the "Double World". Homo Virtualis 2019, 2, 108-112. [CrossRef]

3. Rossi, A. La Città Analoga [The Analogous City]; Universitas Studiorum: Mantova, Italian, 1976.

4. Stella, K.; Christos, F. Building sustainability through integrated design process: Balancing acoustic comfort with energy performance, air quality and fire protection in buildings. In Proceedings of the Echopolis International Conference Proceeedings, Athens, Greece, 30 September-2 October 2013.

5. Psatha, E.; Deffner, A.; Psycharis, Y. Defining the Quality of Urban Life: Which Factors Should Be Considered? In Proceedings of the European Regional Science Association, 51st European Congress, Barcelona, Spain, 2011. Available online: https://www. researchgate.net/publication/254456851_Defining_the_quality_of_urban_life_Which_factors_should_be_considecon (accessed on 18 August 2020).

6. $\quad$ Brueckner, J.K.; Helsley, R.W. Sprawl and Blight. J. Urban Econ. 2011, 69, 205-213. [CrossRef]

7. Berglund, B.; Lindvall, T.; Schwela, D.H.; World Health Organization; Occupational and Environmental Health Team. Guidelines for Community Noise; World Health Organization: Geneva, Switzerland, 1999.

8. Munang, R.T.; Thiaw, I.; Rivington, M. Ecosystem Management: Tomorrow's Approach to Enhancing Food Security under a Changing Climate. Sustainability 2011, 3, 937-954. [CrossRef]

9. $\quad$ Elmqvist, T.; Setälä, H.; Handel, S.; van der Ploeg, S.; Aronson, J.; Blignaut, J.; Gómez-Baggethun, E.; Nowak, D.; Kronenberg, J.; de Groot, R. Benefits of Restoring Ecosystem Services in Urban Areas. Curr. Opin. Environ. Sustain. 2015, 14, 101-108. [CrossRef]

10. Dijkstra, L.D.; Dominicis, L. Report on the Quality of Life in European Cities. European Commission, 2020. pp. 82-83. Available online: https:/ / www.researchgate.net/publication/344629322_Report_on_the_Quality_of_Life_in_European_Cities_2020 (accessed on 15 January 2021).

11. European Commission. Quality of Life in European Cities, 2020, European Commission. Directorate-General for Regional and Urban Policy. 2016, p. 125. Available online: https://ec.europa.eu/regional_policy/en/information/publications/studies/2016 / quality-of-life-in-european-cities-2015 (accessed on 15 January 2021).

12. OFYPEKA-Acoustic Environment. Available online: https://ekpaa.ypeka.gr/perivallontikes-thematikes/akoustiko-perivallon/ dedomena-ekthesewn-katastasis-akoustiko/ (accessed on 11 April 2021). 
13. Casado Novas, J.; Muntan Gregori, N.; Zapata Gonzlez, L.; Mills Nicuesa, A. 2017 Barcelona Strategic Noise Map: Current, Real, and Sensitive to the Noise Management Needs of the City. In Proceedings of the INTER-NOISE NOISE-CON Congress and Conference Proceedings, Madrid, Spain, 16-19 June 2019; Volume 259, pp. 3107-3114.

14. Barcelona: Urban Pollution. Available online: https://geographyfieldwork.com/BarcelonaPollution1.htm (accessed on 11 April 2021).

15. Masson, B.; Pottier, G. Plan de Prévention du Bruit dans l’Environnement (PPBE) de la Métropole Aix-Marseille-Provence sur le Territoire Marseille-Provence, Préparé pour Métropole Aix Marseille Provence-Territoire Marseille Provence. Impédance Ingénierie. p. 29. Available online: www.impedance.fr (accessed on 20 February 2021).

16. Environmental Noise-European Environment Agency. Available online: https://www.eea.europa.eu/airs/2018/environmentand-health/environmental-noise (accessed on 11 April 2021).

17. Hsu, H. How Can Cities Be Designed to Combat Noise? Available online: https://iands.design/articles/33122/how-can-citiesbe-designed-combat-noise (accessed on 11 April 2021).

18. Percentage of Urban Population Exposed to Noise Level Lden > 55 DB-European Health Information Gateway. Available online: https:/ / gateway.euro.who.int/en/indicators/enhis_52-percentage-of-urban-population-exposed-to-noise-level-lden$55-\mathrm{db} /$ visualizations/\#id=21428 (accessed on 11 April 2021).

19. Salomons, E. QSIDE, Noise and Quietness in Cities. Available online: http://www.qside.se/overview.html (accessed on 17 March 2021).

20. Lee, K.A.; Lee, J.R.; Bell, P. A Review of Citizen Science within the Earth Sciences: Potential Benefits and Obstacles. Proc. Geol. Assoc. 2020, 131, 605-617. [CrossRef]

21. Zhang, D.; Huang, Q.; He, C.; Wu, J. Impacts of Urban Expansion on Ecosystem Services in the Beijing-Tianjin-Hebei Urban Agglomeration, China: A Scenario Analysis Based on the Shared Socioeconomic Pathways. Resour. Conserv. Recycl. 2017, 125, 115-130. [CrossRef]

22. Pace, G. Ways of Thinking and Looking at the Mediterranean City; MPRA Paper; University Library of Munich: München, Germany, 2003.

23. Bobolos, N. Urban Design and City Regeneration: The Experience of Athens. Ph.D. Thesis, Panteion University of Social and Political Sciences, Athens, Greece, 2016.

24. Oikonomou, M. The Greek Urban Block since the Establishment of the Greek State in 19th Century. A Chronicle about Morphology and Urban Form. Int. Plan. Hist. Soc. Proc. 2016, 17. [CrossRef]

25. Dubois-Taine, G.; Chalas, Y. La ville émergente. Inf. Géographique 1997, 62, 236.

26. Rogers, R. Towards an Urban Renaissance; Taylor \& Francis Group; Spon Press: London, UK, 2002; ISBN 978-0-203-49774-6.

27. Global Cities Research Institute, RMIT University, Cities for the Future: Innovative and Principles-Based Approaches to Urban Equity, Sustainability and Governance I UN Global Compact. Available online: https://www.unglobalcompact.org/library/1591 (accessed on 11 April 2021).

28. Matsumoto, T. Compact City Policies: A Comparative Assessment IEn I OECD. Available online: https://www.oecd.org/ greengrowth/compact-city-policies-9789264167865-en.htm (accessed on 11 April 2021).

29. Westerink, J.; Haase, D.; Bauer, A.; Ravetz, J.; Jarrige, F.; Aalbers, C.B.E.M. Dealing with Sustainability Trade-Offs of the Compact City in Peri-Urban Planning Across European City Regions. Eur. Plan. Stud. 2013, 21, 473-497. [CrossRef]

30. Kaido, K. The European Model of A Compact City. Jpn. J. Real Estate Sci. 2001, 15, 8-17. [CrossRef]

31. Houl, M. Sustainable Regeneration in Urban Areas, URBACT II Capitalization; URBACT: Saint Denis, French, 2015 ; pp. 6-14.

32. Kyvelou, S.; Sinou, M.; Baer, I.; Papadopoulos, T. Developing a South-European Eco-Quarter Design and Assessment Tool Based on the Concept of Territorial Capital; INTECH Open Access Publisher: London, UK, 2012. [CrossRef]

33. Bailey, G. Time Perspectives, Palimpsests and the Archaeology of Time. J. Anthropol. Archaeol. 2007, 26, 198-223. [CrossRef]

34. Turgut, H. Istanbul: The City as an Urban Palimpsest. Cities 2021, 112, 103131. [CrossRef]

35. Colmenares-Roa, T.; Figueroa-Perea, J.G.; Pelcastre-Villafuerte, B.; Cervantes-Molina, L.; Juárez-Ramirez, C.; Guadarrama, J.; Ramirez-Hernández, N.; Pérez Zepeda, M.U.; Peláez-Ballestas, I. Vulnerability as a Palimpsest: Practices and Public Policy in a Mexican Hospital Setting. Health (N. Y.) 2021. [CrossRef]

36. West, P. Translations, Palimpsests, and Politics. Environmental Anthropology Now. Ethnos 2020, 85, 118-123. [CrossRef]

37. Schafer, R.M. The Tuning of the World; Knopf: New York, NY, USA, 1977; ISBN 978-0-394-40966-5.

38. Fowler, M.D. Soundscape as a Design Strategy for Landscape Architectural Praxis. Des. Stud. 2013, 34, 111-128. [CrossRef]

39. Oldoni, D.; De Coensel, B.; Bockstael, A.; Boes, M.; De Baets, B.; Botteldooren, D. The Acoustic Summary as a Tool for Representing Urban Sound Environments. Landsc. Urban Plan. 2015, 144, 34-48. [CrossRef]

40. Schafer, R.M. The Soundscape: Our Sonic Environment and the Tuning of the World; Simon and Schuster: New York, NY, USA, 1993; ISBN 978-1-59477-668-7.

41. Krause, B. The Great Animal Orchestra (Enhanced): Finding the Origins of Music in the World's Wild Places; Little, Brown: Boston, MA, USA, 2012; ISBN 978-0-316-21249-6.

42. Henry, C.S.; Wells, M.M. Acoustic Niche Partitioning in Two Cryptic Sibling Species of Chrysoperla Green Lacewings That Must Duet before Mating. Anim. Behav. 2010, 80, 991-1003. [CrossRef]

43. Krause, B. Voices of the Wild: Animal Songs, Human Din, and the Call to Save Natural Soundscapes; Yale University Press: London, UK, 2015; ISBN 978-0-300-21644-8. 
44. Truax, B. Acoustic Communication; Greenwood Publishing Group: Westport, CT, USA, 2001; ISBN 978-1-56750-536-8.

45. Korkontzila, A.; Karapostoli, A.; Tsaligopoulos, A.; Matsinos, Y.G. Assessing the Effects of Noise on Sound Identities of Historical Landmarks. Acoustics 2020, 2, 719-739. [CrossRef]

46. Bee, M.A. Finding a Mate at a Cocktail Party: Spatial Release from Masking Improves Acoustic Mate Recognition in Grey Treefrogs. Anim. Behav. 2008, 75, 1781-1791. [CrossRef]

47. Fishenden, J. Sounds of Time and Place. Leonardo 2017, 50, 12-19. [CrossRef]

48. Villanueva-Rivera, L.J.; Pijanowski, B.C.; Doucette, J.; Pekin, B. A Primer of Acoustic Analysis for Landscape Ecologists. Landsc. Ecol. 2011, 26, 1233. [CrossRef]

49. Patella, S.M.; Aletta, F.; Mannini, L. Assessing the Impact of Autonomous Vehicles on Urban Noise Pollution. Noise Mapp. 2019, 6, 72-82. [CrossRef]

50. Ajanovic, A.; Haas, R. Dissemination of Electric Vehicles in Urban Areas: Major Factors for Success. Energy 2016, 115, 1451-1458. [CrossRef]

51. Fagnant, D.J.; Kockelman, K. Preparing a Nation for Autonomous Vehicles: Opportunities, Barriers and Policy Recommendations. Transp. Res. Part Policy Pract. 2015, 77, 167-181. [CrossRef]

52. Maffei, L.; Masullo, M. Electric Vehicles and Urban Noise Control Policies. Arch. Acoust. 2014, 39, 333-341. [CrossRef]

53. Campello-Vicente, H.; Peral-Orts, R.; Campillo-Davo, N.; Velasco-Sanchez, E. The Effect of Electric Vehicles on Urban Noise Maps. Appl. Acoust. 2017, 116, 59-64. [CrossRef]

54. Can, A.; Leclercq, L.; Lelong, J.; Botteldooren, D. Traffic Noise Spectrum Analysis: Dynamic Modeling vs. Experimental Observations. Appl. Acoust. 2010, 71, 764-770. [CrossRef]

55. Lan, Z.; He, C.; Cai, M. Urban Road Traffic Noise Spatiotemporal Distribution Mapping Using Multisource Data. Transp. Res. Part Transp. Environ. 2020, 82, 102323. [CrossRef]

56. Wang, Z.; Lei, T.; Chang, X.; Shi, X.; Xiao, J.; Li, Z.; He, X.; Zhu, J.; Yang, S. Optimization of a Biomass Briquette Fuel System Based on Grey Relational Analysis and Analytic Hierarchy Process: A Study Using Cornstalks in China. Appl. Energy 2015, 157, 523-532. [CrossRef]

57. Pallas, M.-A.; Kennedy, J.; Walker, I.; Chatagnon, R.; Berengier, M.; Lelong, J. Noise Emission of Electric and Hybrid Electric Vehicles: Deliverable FOREVER ( $N^{\circ}$ Forever WP2_D2-1-V4); Institut Français des Sciences et Technologies des Transports, de 1'Aménagement et des Réseaux: Champs-sur-Marne, France, 2015; p. 135.

58. Ismail, M.R. Sound Preferences of the Dense Urban Environment: Soundscape of Cairo. Front. Archit. Res. 2014, 3, 55-68. [CrossRef]

59. Han, X.; Huang, X.; Liang, H.; Ma, S.; Gong, J. Analysis of the Relationships between Environmental Noise and Urban Morphology. Environ. Pollut. 2018, 233, 755-763. [CrossRef]

60. Matsinos, Y.G.; Tsaligopoulos, A.; Economou, C. Identifying the Quiet Areas of a Small Urban Setting: The Case of Mytilene. Glob. Nest J. 2017, 19, 17-28. [CrossRef]

61. Tsaligopoulos, A.; Economou, C.; Matsinos, Y.G. Identification, Prioritization, and Assessment of Urban Quiet Areas. Available online: www.igi-global.com/chapter/identification-prioritization-and-assessment-of-urban-quiet-areas/198160 (accessed on 25 February 2021).

62. Kabisch, N. Ecosystem Service Implementation and Governance Challenges in Urban Green Space Planning-The Case of Berlin, Germany. Land Use Policy 2015, 42, 557-567. [CrossRef]

63. Rey Gozalo, G.; Barrigón Morillas, J.M.; Montes González, D.; Atanasio Moraga, P. Relationships among Satisfaction, Noise Perception, and Use of Urban Green Spaces. Sci. Total Environ. 2018, 624, 438-450. [CrossRef] [PubMed]

64. Bolund, P.; Hunhammar, S. Ecosystem Services in Urban Areas. Ecol. Econ. 1999, 29, 293-301. [CrossRef]

65. Chiesura, A. The Role of Urban Parks for the Sustainable City. Landsc. Urban Plan. 2004, 68, 129-138. [CrossRef]

66. Azkorra, Z.; Pérez, G.; Coma, J.; Cabeza, L.F.; Bures, S.; Álvaro, J.E.; Erkoreka, A.; Urrestarazu, M. Evaluation of Green Walls as a Passive Acoustic Insulation System for Buildings. Appl. Acoust. 2015, 89, 46-56. [CrossRef]

67. Govindarajulu, D. Urban Green Space Planning for Climate Adaptation in Indian Cities. Urban Clim. 2014, 10, 35-41. [CrossRef]

68. Fuller, R.A.; Gaston, K.J. The Scaling of Green Space Coverage in European Cities. Biol. Lett. 2009, 5, 352-355. [CrossRef]

69. Goddard, M.A.; Dougill, A.J.; Benton, T.G. Scaling up from Gardens: Biodiversity Conservation in Urban Environments. Trends Ecol. Evol. 2010, 25, 90-98. [CrossRef]

70. Goddard, M.A.; Dougill, A.J.; Benton, T.G. Why Garden for Wildlife? Social and Ecological Drivers, Motivations and Barriers for Biodiversity Management in Residential Landscapes. Ecol. Econ. 2013, 86, 258-273. [CrossRef]

71. Tsaligopoulos, A.; Karapostoli, A.; Radicchi, A.; Economou, C.; Kyvelou, S.; Matsinos, Y.G. Ecological Connectivity of Urban Quiet Areas: The Case of Mytilene, Greece. Cities Health 2019, 5, 20-32. [CrossRef]

72. LaPoint, S.; Balkenhol, N.; Hale, J.; Sadler, J.; Ree, R.v.d. Ecological Connectivity Research in Urban Areas. Funct. Ecol. 2015, 29, 868-878. [CrossRef]

73. Hansen, R.; Pauleit, S. From Multifunctionality to Multiple Ecosystem Services? A Conceptual Framework for Multifunctionality in Green Infrastructure Planning for Urban Areas. AMBIO 2014, 43, 516-529. [CrossRef] [PubMed]

74. Adami, C.; Ofria, C.; Collier, T.C. Evolution of Biological Complexity. Proc. Natl. Acad. Sci. USA 2000, 97, 4463-4468. [CrossRef] [PubMed]

75. Chick, G. Cultural Complexity: The Concept and Its Measurement. Cross-Cult. Res. 1997, 31, 275-307. [CrossRef] 
76. Krause, B.; Farina, A. Using Ecoacoustic Methods to Survey the Impacts of Climate Change on Biodiversity. Biol. Conserv. 2016, 195, 245-254. [CrossRef]

77. Pieretti, N.; Farina, A.; Morri, D. A New Methodology to Infer the Singing Activity of an Avian Community: The Acoustic Complexity Index (ACI). Ecol. Indic. 2011, 11, 868-873. [CrossRef]

78. Pieretti, N.; Farina, A. Application of a Recently Introduced Index for Acoustic Complexity to an Avian Soundscape with Traffic Noise. J. Acoust. Soc. Am. 2013, 134, 891-900. [CrossRef]

79. Acerbi, A.; Kendal, J.; Tehrani, J.J. Cultural Complexity and Demography: The Case of Folktales. Evol. Hum. Behav. 2017, 38, 474-480. [CrossRef]

80. Bridgewater, P.; Rotherham, I.D. A Critical Perspective on the Concept of Biocultural Diversity and Its Emerging Role in Nature and Heritage Conservation. People Nat. 2019, 1, 291-304. [CrossRef]

81. Rozzi, R.; May, R.H.; Chapin, F.S., III; Massardo, F.; Gavin, M.C.; Klaver, I.J.; Pauchard, A.; Nuñez, M.A.; Simberloff, D. (Eds.) From Biocultural Homogenization to Biocultural Conservation; Ecology and Ethics; Springer International Publishing: Cham, Switzerland, 2018; Volume 3, ISBN 978-3-319-99512-0.

82. Kyvelou, S.S.I.; Ierapetritis, D.G. Fostering Spatial Efficiency in the Marine Space, in a Socially Sustainable Way: Lessons Learnt From a Soft Multi-Use Assessment in the Mediterranean. Front. Mar. Sci. 2021, 8, 225. [CrossRef]

83. Russo, A.; Ommeren, J.V.; Dimitropoulos, A. The Environmental and Welfare Implications of Parking Policies; Organisation for Economic Cooperation and Development (OECD): Paris, France, 2019. [CrossRef]

84. Shoup, D.C. Cruising for Parking. Transp. Policy 2006, 13, 479-486. [CrossRef]

85. Kapsilamis, A. Athens Urban Block-In Search for Improvement in the Inner-City Living Written by Alexandros Kapsilamis; MAS Housing ETH Zürich: Zürich, Switzerland, 2012.

86. Cavoli, C.; Phillips, B.; Cohen, T.; Jones, P. Social and Behavioural Questions Associated with Automated Vehicles: A Literature Review; Department for Transport: London, UK, 2017; p. 124.

87. Orski, K. Policies Affecting Automobile Use, Innovation Fact Sheet N o 1.1.2.-1.9.1. In International Mobility Observatory; Cooperative Mobility Program, Center for Technology, Policy and Industrial Development, Massachusetts Institute of Technology: Cambridge, MA, USA, 2001.

88. Raibaud, Y. «La Ville Durable Creuse les Inégalités». Available online: https:/ /lejournal.cnrs.fr/billets/la-ville-durable-creuseles-inegalites (accessed on 3 April 2021).

89. Bissell, D.; Birtchnell, T.; Elliott, A.; Hsu, E.L. Autonomous Automobilities: The Social Impacts of Driverless Vehicles. Curr. Sociol. 2020, 68, 116-134. [CrossRef]

90. Self Driven Cars. Available online: https://www.drishtiias.com/current-affairs-news-analysis-editorials/news-analysis/07-052019/print (accessed on 3 April 2021).

91. European Parliament Self-Driving Cars in the EU: From Science Fiction to Reality I News I European Parliament. Available online: https:/ / www.europarl.europa.eu/news/en/headlines/economy/20190110STO23102/self-driving-cars-in-the-eu-fromscience-fiction-to-reality (accessed on 3 April 2021).

92. Transportxtra ParkAV Project Explores How Connected and Autonomous Vehicle. Available online: https://www.transportxtra. com/publications / parking-review/news/64952/parkav-project-explores-how-connected-and-autonomous-vehicles-interactwith-kerbside-car-parks-and-mobility-service-providers/ (accessed on 3 April 2021).

93. HERE How Autonomous Vehicles Could Relieve or Worsen Traffic Congestion. Available online: https://www.here.com/sites/ g/files/odxslz166/files/2018-12/HERE_How_autonomous_vehicles_could_relieve_or_worsen_traffic_congestion_white_ paper.pdf (accessed on 3 April 2021).

94. Milakis, D.; van Wee, B. Chapter 4-Implications of vehicle automation for accessibility and social inclusion of people on low income, people with physical and sensory disabilities, and older people. In Demand for Emerging Transportation Systems; Antoniou, C., Efthymiou, D., Chaniotakis, E., Eds.; Elsevier: Amsterdam, The Netherlands, 2020; pp. 61-73, ISBN 978-0-12-815018-4.

95. Friedrich, B. The Effect of Autonomous Vehicles on Traffic. In Autonomous Driving: Technical, Legal and Social Aspects; Maurer, M., Gerdes, J.C., Lenz, B., Winner, H., Eds.; Springer: Berlin/Heidelberg, Germany, 2016; pp. 317-334, ISBN 978-3-662-48847-8.

96. Barter, P. An End to Mass Car Ownership without Draconian Policies? (And a Tribute to Chris Bradshaw). Available online: https:/ / www.reinventingtransport.org/2019/02/end-mass-car-ownership.html (accessed on 3 April 2021).

97. Grisoni, A.; Madelenat, J. Etude n³: Le Véhicule Autonome: Quel Rôle Dans la Transition Ecologique des Mobilités ? Une Recherche Menée par La Fabrique Ecologique sur Commande du Forum des Vies Mobiles. pp. 28, 70, 109, 112. Available online: https: / / www.actu-environnement.com/media/pdf/news-37182-rapport-complet-etude-vehicule-autonome-forumvies-mobiles-mars-2021.pdf (accessed on 23 February 2021).

98. European Union Communication from the Commission to the European Parliament, the Council, the European Economic and Social Committee, the Committee of the Regions on the Road to Automated Mobility: An EU Strategy for Mobility of the Future COM/2018/283 Final. Available online: https://eur-lex.europa.eu/legal-content/EN/TXT/?uri=CELEX\%3A52018DC0283 (accessed on 3 April 2021).

99. Fraedrich, E.; Heinrichs, D.; Bahamonde-Birke, F.J.; Cyganski, R. Autonomous Driving, the Built Environment and Policy Implications. Transp. Res. Part Policy Pract. 2019, 122, 162-172. [CrossRef] 
100. Shaver, K. City Planners Eye Self-Driving Vehicles to Correct Mistakes of the 20th-Century Auto. Available online: https:/ www. washingtonpost.com/transportation/2019/07/20/city-planners-eye-self-driving-vehicles-correct-mistakes-th-century-auto/ (accessed on 10 August 2020).

101. Punzo, G.; Mayfield, M. Car Ownership Is Likely to Become a Thing of the Past-And So Could Public Transport. Available online: http: / / theconversation.com/car-ownership-is-likely-to-become-a-thing-of-the-past-and-so-could-public-transport110550 (accessed on 3 April 2021).

102. PTUA. PTUA Myth: Self-Driving Cars Will Cut Congestion and Make Public Transport Obsolete I Public Transport Users Association; Public Transport Users Association: Victoria, Australia, 2020.

103. Chaplin, T. Here Come The Robot Cars. Available online: https://www.planning.org/planning/2017/apr/robotcars/ (accessed on 3 April 2021).

104. Shale-Helster, T. End Personal Car Ownership, MPs Say. Available online: https://www.autoexpress.co.uk/car-news /consumernews / 107701/end-personal-car-ownership-mps-say (accessed on 3 April 2021).

105. Cohen, M.J. The Future of Automobile Society: A Socio-Technical Transitions Perspective. Technol. Anal. Strateg. Manag. 2012, 24, 377-390. [CrossRef]

106. Alpert, D. Latest Data Shows Plenty of Car-Free Living in DC. Available online: https://ggwash.org/view/12290/latest-datashows-plenty-of-car-free-living-in-dc (accessed on 3 April 2021).

107. Garfield, L. 13 Cities That Are Starting to Ban Cars. Available online: https://www.businessinsider.com/cities-going-car-freeban-2017-8 (accessed on 3 April 2021).

108. Boehm, Z. Expert Pitch: The Future Is Now for Robot Cars. Available online: https://news.fsu.edu/news/expert-pitches/2017 /01/23/expert-pitch-future-now-robot-cars/ (accessed on 3 April 2021). 